\title{
Development of $\mathrm{W}-\mathrm{Cu}-\mathrm{Ni}$ Electrical Contact Materials with Enhanced Mechanical Properties by Spark Plasma Sintering Process
}

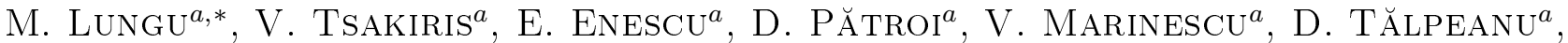
D. PAVElescu ${ }^{b}$, Gh. DUmitrescu ${ }^{c}$ AND A. RADUlian ${ }^{c}$

${ }^{a}$ National Institute for Research and Development in Electrical Engineering, ICPE-CA

Splaiul Unirii no. 313, 030138 Bucharest - 3, Romania

${ }^{b}$ POLITEHNICA University of Bucharest (UPB)

Splaiul Independenţei no. 313, 060042, Bucharest — 6, Romania

${ }^{c}$ Icpe SA, Splaiul Unirii no. 313, 030138 Bucharest - 3, Romania

This study reports on the development of some $\mathrm{W}-\mathrm{Cu}-\mathrm{Ni}$ materials for use as electrical contacts for low voltage vacuum switching contactors for nominal currents up to $630 \mathrm{~A}$. The contact materials with $85 \mathrm{wt} \% \mathrm{~W}$, $12-14 \mathrm{wt} \% \mathrm{Cu}$ and 1-3 wt\% $\mathrm{Ni}$ were obtained by spark plasma sintering process in vacuum. From very finely dispersed $\mathrm{W}-\mathrm{Cu}-\mathrm{Ni}$ powder mixtures there were produced sintered electrical contact pieces that were investigated in terms of physical, microstructural, mechanical, and functional properties. The material sintered at $1200{ }^{\circ} \mathrm{C}$ exhibited a near fully dense structure with very low porosity and enhanced mechanical properties: hardness of maximum $480 \mathrm{HV} 1$ and elastic modulus of maximum $220 \mathrm{GPa}$ and low chopping current of maximum $1.77 \mathrm{~A}$.

DOI: $10.12693 /$ APhysPolA.125.327

PACS: 81.16.-c, 81.05.Ni, 81.07.Wx, 81.20.Ev

\section{Introduction}

$\mathrm{W}-\mathrm{Cu}$ contact materials are widely used as arcing contacts in vacuum switching devices such as circuit breakers, contactors, and load switches [1-14]. These materials are heterogeneous compound materials, consisting of a refractory component - W and a ductile component - $\mathrm{Cu}$. W yields high melting point, high density, high hardness, low conductivity, low vapor pressure and low arc erosion, while $\mathrm{Cu}$ yields high electrical and thermal conductivity and lower melting point than $\mathrm{W}[2-13]$. In addition, $\mathrm{W}$ has high withstand voltage in vacuum, whereas $\mathrm{Cu}$ prevents any overheating of the switching surface and contributes to good arc interruption and a low chopping current [12].

Generally, $\mathrm{W}-\mathrm{Cu}$ materials are produced by liquid phase sintering through infiltration, activated sintering with small amounts of transition metals such as $\mathrm{Ni}, \mathrm{Co}$, $\mathrm{Fe}, \mathrm{Zn}[2-13]$, etc. However, it is difficult to fabricate alloy and composites with homogeneous microstructure, because $\mathrm{W}$ and $\mathrm{Cu}$ have no solubility of each other through the whole composition [7]. In $\mathrm{W}-\mathrm{Cu}$ composites, $\mathrm{Ni}$ addition improves the wetting and adhesion of $\mathrm{Cu}$ and $\mathrm{W}$ and facilitates nonporous composite production $[6,8]$. With the recent progress in mechanical alloying of powder mixtures of $\mathrm{W}-\mathrm{Cu}[10]$ and their processing by new powder metallurgy techniques, it is now possible to obtain fully dense composites with homogeneous microstructure. In this regard, spark plasma sintering (SPS), also known as field assisted sintering technique (FAST), has been shown to be an effective non-conventional innovative sintering technique to consoli-

*corresponding author; e-mail: magdalena.lungu@icpe-ca.ro date materials with maintaining their structure features [15-18]. The SPS process is based on a modified hot pressing process in which the electric current does not run through an external heater, but directly through the pressing mould and the component. Thanks to the application of a pulsed electric current and the resulting "spark plasma sintering effect", very fast pre-heating times and therefore short process cycles are realized. As a result, grain growth and the development of equilibrium states can be suppressed that enables obtaining of materials with previously unachievable compositions and properties [17].

In this work, $\mathrm{W}-\mathrm{Cu}-\mathrm{Ni}$ contact materials with near fully dense structure and enhanced mechanical properties were developed successfully by SPS process starting from very finely dispersed powder mixtures containing $85 \mathrm{wt} \% \mathrm{~W}, 12-14 \mathrm{wt} \% \mathrm{Cu}$ and $1-3 \mathrm{wt} \% \mathrm{Ni}$ prepared by mechanical milling of $\mathrm{W}, \mathrm{Cu}$, and $\mathrm{Ni}$ very fine powders.

\section{Experimental details}

Very pure $(\geq 99 \%)$ and fine powders (maximum size up to $32 \mu \mathrm{m}$ ) of $\mathrm{W}$ (H.C. Starck GmbH, Germany), $\mathrm{Cu}$ (Ecka Granules GmbH, Germany) and Ni (Merck, Germany) were used as starting materials. The $\mathrm{W}-\mathrm{Cu}-\mathrm{Ni}$ powder mixtures containing 1 wt $\%$ stearic acid $(97 \%$, Acros Organics, Belgium) were mechanically milled for $10 \mathrm{~h}$ in a stainless steel grinding bowl of $500 \mathrm{~mL}$ volume placed in a planetary mono mill (Pulverisette 6, Fritsch GmbH, Germany) using stainless steel balls as milling bodies. The balls to powder mixture weight ratio was 10:1 and milling speed was $300 \mathrm{rpm}$. The stearic acid was added as a process control agent to avoid powders from welding with bowl and balls during collision and to maintain balance of welding and fracturing.

Sintered pieces with diameter of $20 \mathrm{~mm}$ and height of 4-5 $\mathrm{mm}$ were achieved by SPS processing using a SPS 
installation of HP D25 type (FCT Systeme GmbH, Germany) equipped with a power supply producing a pulsed DC signal with a maximum intensity value of $8 \mathrm{kA}$ at a voltage of $8 \mathrm{~V}$. In this aim, $19 \pm 1 \mathrm{~g}$ of $\mathrm{W}-\mathrm{Cu}-\mathrm{Ni}$ powder mixture was charged into graphite press mould having inner diameter of $20.8 \mathrm{~mm}$. After the mould was placed into the chamber of the SPS installation, an initial pressure of $16 \mathrm{MPa}$ was applied. Then the pressure was increased to $40 \mathrm{MPa}$ and maintained constant until the end of the dwell. A continuous heating in vacuum at $100^{\circ} \mathrm{C} / \mathrm{min}$ to reach the sintering temperature of $1100^{\circ} \mathrm{C}$ and $1200^{\circ} \mathrm{C}$ was performed with a dwell time of $5 \mathrm{~min}$. DC pulses pattern was: pulse duration of $12 \mathrm{~ms}$, pause duration of $2 \mathrm{~ms}$, and 1 pulse per burst. After the end of sintering dwell, the mould and sintered piece were cooled rapidly in vacuum with a rate of $100^{\circ} \mathrm{C} / \mathrm{min}$.

Surface morphology of the powder mixtures was investigated by scanning electron microscopy (SEM) by using a CrossBeam workstation composed of a focused ion beam system and a scanning electron microscope ( $\mathrm{Au}-$ riga, Carl Zeiss SMT, Germany). The SEM micrographs were acquired with a detector of secondary electrons at the magnification of $20,000 \times$ and the acceleration voltage of $21 \mathrm{kV}$.

The $\mathrm{W}-\mathrm{Cu}-\mathrm{Ni}$ particle size (hydrodynamic diameter) and polydispersity were measured at a temperature of $25^{\circ} \mathrm{C}$ and a scattering angle of $90^{\circ}$ into aqueous suspensions of $0.01 \% \mathrm{v} / \mathrm{v}$ by dynamic light scattering (DLS), by using a 90Plus particle size analyzer (Brookhaven Instruments Corporation, USA) equipped with $35 \mathrm{~mW}$ solid state laser having $660 \mathrm{~nm}$ wavelength.

The apparent density of $\mathrm{W}, \mathrm{Cu}$ and $\mathrm{Ni}$ powders and $\mathrm{W}-\mathrm{Cu}-\mathrm{Ni}$ powder mixtures was determined at room temperature by the funnel method using a Hall flowmeter funnel.

The sintered density was determined at a temperature of $22{ }^{\circ} \mathrm{C}$ with a hydrostatic balance (XS204; Mettler-Toledo LLC, USA) using ethyl alcohol as immersion liquid. The relative density was computed as the ratio of the sintered density to the theoretical density of $\mathrm{W}-\mathrm{Cu}-\mathrm{Ni}$ contact material.

The Vickers hardness (HV1/15) and elastic modulus of the sintered pieces were determined by Oliver and Pharr computational method, by using a microhardness tester (CSM Instruments, Switzerland) with an indentation load of $9.8 \mathrm{~N}$, approach speed of the indenter of $2 \mu \mathrm{m} / \mathrm{min}$, loading and unloading rate of $20 \mathrm{~N} / \mathrm{min}$ and dwell time of $15 \mathrm{~s}$.

The microstructure was examined with an optical microscope (NU2-VEB, Carl Zeiss, Germany) on sintered pieces polished with diamond slurry and etched for $20 \mathrm{~s}$ with conventional Murakami's solution.

The chopping current measurements were performed on pairs of two $\mathrm{W}-\mathrm{Cu}-\mathrm{Ni}$ contact pieces of each investigated material, mechanically fastened on $\mathrm{Cu}$ supports by using a testing equipment (made by Icpe SA and UPB, Romania) in the following conditions: pressure in the vacuum arc quenching chamber of $10^{-4} \mathrm{~Pa}$, injected current of $25-30 \mathrm{~A}$, opening velocity of the contacts of $1.5 \mathrm{~m} / \mathrm{s}$, number of determinations of 31 .

\section{Results and discussions}

The SEM micrographs in Fig. 1 show the surface morphology of the $\mathrm{W}-\mathrm{Cu}-\mathrm{Ni}$ powder mixtures.

As illustrated in Fig. 1, both $\mathrm{W}-\mathrm{Cu}-\mathrm{Ni}$ composite powders have a flaky morphology with average particle size ranging from $400 \pm 50 \mathrm{~nm}$ for small particles to $1500 \pm 100 \mathrm{~nm}$ for large particles.

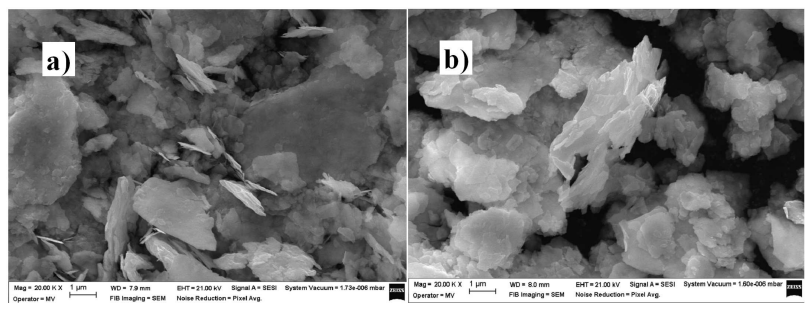

Fig. 1. SEM micrographs of the powder mixtures: (a) $\mathrm{W}-\mathrm{Cu}-\mathrm{Ni} 85-14-1$ and (b) $\mathrm{W}-\mathrm{Cu}-\mathrm{Ni} 85-12-3$.

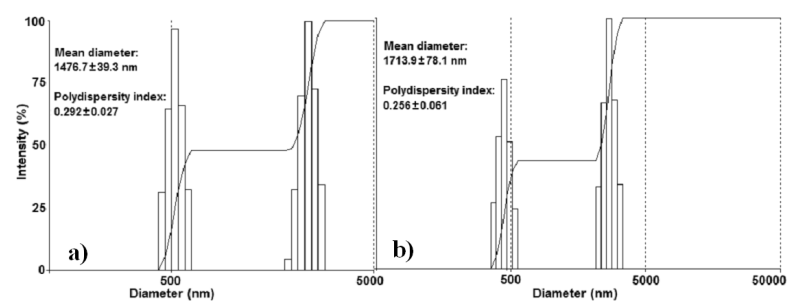

Fig. 2. Particle size distribution histograms of the powder mixtures: (a) $\mathrm{W}-\mathrm{Cu}-\mathrm{Ni} \quad 85-14-1$ and (b) $\mathrm{W}-\mathrm{Cu}-\mathrm{Ni} 85-12-3$.

The particle size distribution histograms of intensity of scattered light versus $\mathrm{W}-\mathrm{Cu}-\mathrm{Ni}$ particle size obtained by DLS are presented in Fig. 2 .

The $\mathrm{W}-\mathrm{Cu}-\mathrm{Ni} 85-14-1$ powder exhibited a bimodal particle size distribution in a narrow range, composed of small particles (size range of 445.67-603.41 nm) and large particles (size range of 1879.68-2745.22 nm), yielding a mean particle hydrodynamic diameter of $1476.7 \pm$ $39.3 \mathrm{~nm}$. The $\mathrm{W}-\mathrm{Cu}-\mathrm{Ni} 85-12-3$ powder exhibited also a bimodal particle size distribution composed of small particles (size range of $370.45-530.46 \mathrm{~nm}$ ) and large particles (size range of $2230.24-3193.57 \mathrm{~nm}$ ), yielding a mean particle hydrodynamic diameter of $1713.9 \pm 78.1 \mathrm{~nm}$.

The hydrodynamic diameter measured in DLS (Fig. 2) is slightly larger than the true particle diameter observed in SEM analysis (Fig. 1). This can be explained by the fact that the hydrodynamic diameter of a particle corresponds to the diameter of a sphere that has the same average diffusion coefficient as the particle being measured and depends on the size of the particle core, its surface structure, concentration and type of ions in the medium [19].

Both $\mathrm{W}-\mathrm{Cu}-\mathrm{Ni}$ composite powders showed good polydispersity, since the polydispersity index that is a measure of the distribution width was $0.292 \pm 0.027$ for the 
TABLE I W-Cu-Ni $85-14-1$ powder and $0.256 \pm 0.061$ for the

Apparent density and theoretical density of $\mathrm{W}, \mathrm{Cu}$, and $\mathrm{Ni}$ powders and $\mathrm{W}-\mathrm{Cu}-\mathrm{Ni}$ powder mixtures.

\begin{tabular}{c|c|c|c|c|c}
\hline \hline Powder type & $\mathrm{W}$ & $\mathrm{Cu}$ & $\mathrm{Ni}$ & \multicolumn{2}{|c}{$\mathrm{W}-\mathrm{Cu}-\mathrm{Ni}$} \\
\cline { 4 - 5 } & & $85-14-1$ & $85-12-3$ \\
\hline $\begin{array}{c}\text { apparent } \\
\text { density }\left[\mathrm{g} / \mathrm{cm}^{3}\right]\end{array}$ & 3.79 & 1.70 & 2.06 & 1.62 & 2.41 \\
$\begin{array}{c}\text { theoretical } \\
\text { density }\left[\mathrm{g} / \mathrm{cm}^{3}\right]\end{array}$ & 19.30 & 8.96 & 8.90 & 16.450 & 16.446 \\
\hline
\end{tabular}

$\mathrm{W}-\mathrm{Cu}-\mathrm{Ni} 85-12-3$ powder. The polydispersity index decreases with particle size increase.

Table I presents the apparent density and theoretical density of $\mathrm{W}, \mathrm{Cu}$ and $\mathrm{Ni}$ powders and $\mathrm{W}-\mathrm{Cu}-\mathrm{Ni}$ powder mixtures while Table II presents some physical, mechanical and functional properties of $\mathrm{W}-\mathrm{Cu}-\mathrm{Ni}$ sintered materials.

TABLE II

Physical, mechanical and functional properties of $\mathrm{W}-\mathrm{Cu}-\mathrm{Ni}$ sintered electrical contact materials.

\begin{tabular}{|c|c|c|c|c|c|c|c|}
\hline \multirow{2}{*}{$\begin{array}{l}\text { Material type/ } \\
\text { sintering } \\
\text { temperature }\left[{ }^{\circ} \mathrm{C}\right]\end{array}$} & \multirow{2}{*}{$\begin{array}{c}\text { Sintered } \\
\text { density } \\
{\left[\mathrm{g} / \mathrm{cm}^{3}\right]}\end{array}$} & \multirow{2}{*}{$\begin{array}{c}\text { Relative } \\
\text { density } \\
{[\%]}\end{array}$} & \multirow{2}{*}{$\begin{array}{c}\text { Porosity } \\
{[\%]}\end{array}$} & \multirow{2}{*}{$\begin{array}{l}\text { Hardness } \\
\mathrm{HV} 1 / 15 \\
{\left[\mathrm{kgf} / \mathrm{mm}^{2}\right]}\end{array}$} & \multirow{2}{*}{$\begin{array}{c}\text { Elastic } \\
\text { modulus } \\
{[\mathrm{GPa}]}\end{array}$} & \multicolumn{2}{|c|}{$\begin{array}{c}\text { Chopping } \\
\text { current [A] }\end{array}$} \\
\hline & & & & & & Avg. & Max. \\
\hline $\begin{array}{c}\mathrm{W}-\mathrm{Cu}-\mathrm{Ni} \\
85-14-1 / 1100\end{array}$ & 15.011 & 91.25 & 8.75 & $387 \pm 24$ & $175 \pm 9$ & 0.99 & 2.65 \\
\hline $\begin{array}{c}\mathrm{W}-\mathrm{Cu}-\mathrm{Ni} \\
85-14-1 / 1200\end{array}$ & 15.793 & 96.01 & 3.99 & $402 \pm 19$ & $189 \pm 7$ & 1.73 & 3.14 \\
\hline $\begin{array}{c}\mathrm{W}-\mathrm{Cu}-\mathrm{Ni} \\
85-12-3 / 1100\end{array}$ & 15.415 & 93.73 & 6.27 & $425 \pm 22$ & $202 \pm 8$ & 2.29 & 3.68 \\
\hline $\begin{array}{c}\mathrm{W}-\mathrm{Cu}-\mathrm{Ni} \\
85-12-3 / 1200\end{array}$ & 16.112 & 97.97 & 2.03 & $463 \pm 17$ & $214 \pm 6$ & 1.77 & 3.94 \\
\hline
\end{tabular}

The apparent density (Table I) of the $\mathrm{W}-\mathrm{Cu}-\mathrm{Ni}$ powder mixtures was influenced mainly by $\mathrm{Cu}$ and $\mathrm{Ni}$ content. As $\mathrm{Cu}$ content was higher and $\mathrm{Ni}$ content was lower the apparent density of the $\mathrm{W}-\mathrm{Cu}-\mathrm{Ni}$ 85-14-1 powder was lower, confirming its smaller grain size than the $\mathrm{W}-\mathrm{Cu}-\mathrm{Ni} 85-12-3$ powder, even if the mechanical milling conditions were the same.

It was found out that the properties of $\mathrm{W}-\mathrm{Cu}-\mathrm{Ni}$ materials (Table II) are dependent on chemical composition and finesses of powders, as well as on sintering temperature. Ni can lower the activation energy of sintering, allowing a lower sintering temperature. By solid state activated sintering there is accelerated $W$ diffusion through transformed disordered grain boundaries [6]. The fast heating rate used in SPS process leads to particles activation and good wetting and sintering necks between neighbor particles form and grow at a lower temperature than in conventional processes [18]. At $1100^{\circ} \mathrm{C}$ even sintering necks occurred, the relative density is $91.25-93.73 \%$, meaning a porosity of $6.27-8.75 \%$. With temperature increase to $1200^{\circ} \mathrm{C}$, since $\mathrm{Cu}$ and $\mathrm{Ni}$ mobility in the $\mathrm{W}$ matrix increased and the diffusion between particles was enhanced, the sintering necks grow fast and the samples were further densified and the pores between particles were reduced to $2.03-3.99 \%$. Thus, a relative density of 96.01-97.97\% was obtained.

All the sintered samples show high densification. Lowest density appears for the $\mathrm{W}-\mathrm{Cu}-\mathrm{Ni} 85-14-1$ material with highest $\mathrm{Cu}$ content, resulting in the lowest microhardness. It occurs due to the nature of low hardness of $\mathrm{Cu}$. As $\mathrm{Cu}$ content decreased and $\mathrm{Ni}$ content in- creased, the microhardness values increased showing better particles bonding. As in the case of density, microhardness and elastic modulus increased with the increase of the sintering temperature. The microhardness and elastic modulus were highest when the porosity was lowest. The $\mathrm{W}-\mathrm{Cu}-\mathrm{Ni}$ contact materials achieved by SPS process showed superior hardness values in comparison with the ones known for $\mathrm{WC}-\mathrm{Cu}$ with $30 \mathrm{wt} \% \mathrm{Cu}$ $\left(\mathrm{HV} \approx 380 \mathrm{kgf} / \mathrm{mm}^{2}\right)$ and $\mathrm{WC}-\mathrm{Ag}$ with $40 \mathrm{wt} \% \mathrm{Ag}$ $\left(\mathrm{HV} \approx 300 \mathrm{kgf} / \mathrm{mm}^{2}\right)$ conventional materials processed by pressing-sintering-infiltration that are mainly used in vacuum contactors [14]. It is an important issue since a hard contact material can improve its functional behavior by minimizing contact sticking in vacuum.

Figure 3 shows the optical micrographs (cross-section) of the $\mathrm{W}-\mathrm{Cu}-\mathrm{Ni}$ contact materials obtained by SPS process.

The microstructure of all the $\mathrm{W}-\mathrm{Cu}-\mathrm{Ni}$ samples is a typical liquid-phase sintering one where necking between W particles can be seen. Due to very short duration of the SPS process of about $30 \mathrm{~min}$, a dense and fine-grained microstructure with a low porosity was achieved, especially for the samples sintered at $1200^{\circ} \mathrm{C}$. Smaller pores are due to diffusion of $\mathrm{Cu}$ in liquid phase during sintering. Knowing that a fine, homogeneous, and fault-free microstructure is a necessary prerequisite for enhanced material performance [2], the obtained results are in good agreement.

It is desirable for the materials used for contact components of vacuum contactors, due to the long service life requirement, to meet particularly high standards. A low 


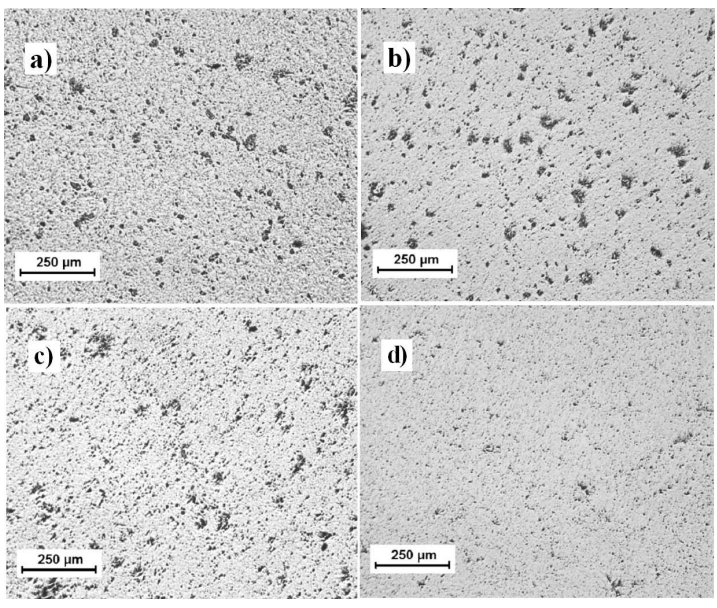

Fig. 3. Optical micrographs of the contact materials: (a) $\mathrm{W}-\mathrm{Cu}-\mathrm{Ni} 85^{-14}-1$ sintered at $1100^{\circ} \mathrm{C}$, (b) $\mathrm{W}-\mathrm{Cu}-\mathrm{Ni} 85-14-1$ sintered at $1200^{\circ} \mathrm{C}$, (c) $\mathrm{W}-\mathrm{Cu}-\mathrm{Ni}$ $85-12-3$ sintered at $1100^{\circ} \mathrm{C}$, and (d) W-Cu-Ni $85-12-3$ sintered at $1200{ }^{\circ} \mathrm{C}(50 \times$ magnification $)$.

welding force is desired, so that the opening of the contact pieces is assured even after transient short-circuit currents. Also, low chopping current (arc current interruption before the natural current zero is reached) with average value below $5 \mathrm{~A}$ is a very important condition to prevent impermissible overvoltages between main contacts on circuit opening [11-13]. The abnormal overvoltages caused by trapped magnetical energy in the load after current chopping can lead to destruction of the circuit components [13].

The both $\mathrm{W}-\mathrm{Cu}-\mathrm{Ni}$ materials processed by SPS at $1100{ }^{\circ} \mathrm{C}$ and $1200^{\circ} \mathrm{C}$ exhibited very good results on functional tests yielding low chopping currents with average values up to $2.29 \mathrm{~A}$ (Table II). As $\mathrm{Cu}$ content decreased and $\mathrm{Ni}$ content increased, the average chopping current values increased from $0.99-1.73 \mathrm{~A}$ to $1.77-2.29 \mathrm{~A}$. The chopping current was lower for the $\mathrm{W}-\mathrm{Cu}-\mathrm{Ni}$ material with smaller particle size.

The results presented in this study recommend the using of the novel contact materials in vacuum contactors. Due to the SPS processing it was possible to obtain reliable contacts with better performance than conventional $\mathrm{W}-\mathrm{Cu}$ contacts.

\section{Conclusions}

$\mathrm{W}-\mathrm{Cu}-\mathrm{Ni}$ electrical contact materials with 12 $14 \mathrm{wt} \% \mathrm{Cu}, 1-3 \mathrm{wt} \% \mathrm{Ni}$ and balance wt\% W were obtained from very finely dispersed $\mathrm{W}, \mathrm{Cu}$, and $\mathrm{Ni}$ powder mixtures that were previously mechanically milled, by using SPS process in vacuum with holding pressure of $40 \mathrm{MPa}$, sintering temperature of $1100^{\circ} \mathrm{C}$ and $1200^{\circ} \mathrm{C}$, dwell time of $5 \mathrm{~min}$ and heating/cooling rate of $100^{\circ} \mathrm{C} / \mathrm{min}$. The obtained results show that the SPS process plays a key role in the achievement of electrical contact materials with enhanced physical, mechanical and functional properties and a dense and fine-grained microstructure. The $\mathrm{W}-\mathrm{Cu}-\mathrm{Ni}$ 85-12-3 material sintered at $1200{ }^{\circ} \mathrm{C}$ exhibited highest mechanical properties with Vickers hardness of $463 \pm 17 \mathrm{kgf} / \mathrm{mm}^{2}$ and elastic modulus of $214 \pm 6 \mathrm{GPa}$, a near fully dense structure with very low porosity of $2.03 \%$ and low average chopping current of $1.77 \mathrm{~A}$ that can lead to an increase of the mechanical and electrical life of vacuum switching devices in which electrical contact pieces are fitted.

\section{Acknowledgments}

This work was financially supported by the Executive Unit for Financing Higher Education, Research, Development and Innovation (UEFISCDI) through the collaborative applied research project PN-II-PT-PCCA, contract no. $34 / 2012$, acronym NeWaLC.

\section{References}

[1] S. Temborius, M. Lindmayer, D. Gentsch, in: Proc. 20th ISDEIV - Int. Symp. on Discharges and Electrical Insulation in Vacuum, Tours (France), Vol. 20, 2002, p. 247.

[2] A. Mondal, A. Upadhyaya, D. Agrawal, Mater. Res. Innov. 14, 355 (2010).

[3] M.H. Maneshian, A. Simchi, J. Alloy Comp. 463 153 (2008).

[4] J.L. Johnson, J.J. Brezovsky, R.M. German, Metall. Mater. Trans. A 36A, 1557 (2005).

[5] B. Ozkal, A. Upadhyaya, M.L. Ovecoglu, R.M. German, Powder Metall. 53, 236 (2010).

[6] A.G. Hamidi, H. Arabi, S. Rastegari, Int. J. Refract. Met. H 29, 538 (2011).

[7] Y.D. Kim, N.L. Oh, S.T. Oh, I.H. Moon, Mater Lett. 51, 420 (2001).

[8] J.S. Lee, I.H. Moon, Verlag Schmid GmbH 2, 1115 (1986).

[9] I. Stefan, N. Nicolicescu, M. Gavrila, Mater. Sci. Forum 672, 276 (2011).

[10] J.C. Kim, S.S. Ryu, Y.D. Kim, I.H. Moon, Scr. Mater. 39, 669 (1998).

[11] H. Haessler, R. Mueller, H. Kippenberg, W. Kuhl, J. Grosse, US Patent 4780582, 1988.

[12] K. Masaru, T. Hitoshi, H. Toshiaki, US Patent, 4299889, 1981.

[13] E.P.A. van Lanen, M. Popov, L. van der Sluis, R.P.P. Smeets, IEEE T. Plasma Sci. 33, 1589 (2005).

[14] R. Grill, P. Kläusler, F.E.-H. Mueller, O. Schrott, H. Hauser, in: Proc. 16th Int. Plansee Seminar, Reutte (Austria), 200 RM20, 2005.

[15] Z.A. Munir, U.A. Tamburini, M. Ohyanagi, J. Mater. Sci. 41, 763 (2006).

[16] M. Omori, Mater. Sci. Eng. A 287, 183 (2000).

[17] H.U. Kessel, Process Eng. cfi/Ber. DKG 86, 145 (2009).

[18] K. Hu, X.Q. Li, C.Y, Y.Y. Li, Trans. Nonferrous Met. Soc. China 21, 493 (2011).

[19] M. Kaszuba, D. McKnight, M.T. Connah, F.K. McNeil-Watson, U. Nobbmann, J. Nanopart. Res. 10, 823 (2008). 